\title{
A COMPARISON BETWEEN AVERAGED SPIKES AND INDIVIDUAL VISUALLY-ANALYZED SPIKES IN ROLANDIC EPILEPTIFORM DISCHARGES
}

\author{
Nadia I.O. Braga', Gilberto M. Manzano', João Antonio M. Nóbrega ${ }^{2}$
}

\begin{abstract}
Purpose:This study compared some morphological features of individual rolandic epileptiform discharges, used to obtain an averaged estimate, with those of the resulting estimate. Method: Twenty-four averaged discharges from EEGs of 24 children showing rolandic spikes were compared with 480 individual discharges used in the averaging. The analysis was based on the occurrence of tangential dipole and "double spike" patterns. Results: In 15 averaged discharges the tangential dipole pattern was found. Individual spikes used in the averaging process displayed the same pattern in $35-100 \%$ of them; in the remaining 9 averaged discharges, up to $20 \%$ of the individual spikes showed the same pattern, although this was not found in the averaged waveforms. "Double spike" pattern was found in 11 of the averaged waveforms and was recognized in $50-100 \%$ of its individual discharges, whereas up to $45 \%$ of individual spikes showed this pattern without expression in the averaged waveform. Conclusion: When visually analyzing an EEG with rolandic spikes, caution should be exercised in characterizing these patterns, since a few discharges showing them may not be expressed in the averaged waveform and the clinical correlations proposed for these patterns may not apply.
\end{abstract}

KEY WORDS: EEG, rolandic epilepsy, tangential dipole, double spike.

\begin{abstract}
Comparação por análise visual entre as espículas promediadas e as espículas individuais nas descargas epileptiformes rolândicas

RESUMO - Objetivo: Comparar as características morfológicas das descargas epileptiformes rolândicas individuais usadas para se obter uma descarga promediada com a resultante promediada. Método: Vinte e quatro descargas promediadas dos EEG de 24 crianças com descargas epileptiformes rolândicas foram comparadas com as 480 descargas individuais utilizadas na promediação. A análise foi baseada na ocorrência de dipolo tangencial e "dupla espícula". Resultados: Em 15 descargas promediadas o dipolo tangencial estava presente. As espículas individuais usadas na promediação mostraram o mesmo padrão em 35-100\% das descargas. Nas 9 descargas promediadas restantes, até $20 \%$ das descargas individuais apresentavam o padrão, embora este não estivesse presente na resultante promediada. 0 padrão "dupla espícula" foi encontrado em 11 descargas promediadas, tendo sido reconhecido em $50-100 \%$ das descargas individuais, enquanto até $45 \%$ das espículas individuais mostraram este padrão sem que este estivesse presente na resultante promediada. Conclusão: Quando se procede à analise visual de um EEG com descargas epileptiformes rolândicas é necessário cuidado na caracterização desses padrões, pois algumas descargas podem apresentá-los sem manter a sua expressão na resultante promediada e as correlações clínicas referentes a esse padrões podem não se aplicar.
\end{abstract}

PALAVRAS-CHAVE: EEG epilepsia rolândica, dipolo tangencial, espícula dupla.

Potential field distribution and morphological characteristics of the rolandic spikes has been studied by computerized analysis using spike averaging ${ }^{1-14}$. Some of these studies suggested the existence of a relationship between two EEG patterns and some clinical features. The association between the detection of tangential dipole pattern (maximal centrotemporal negativity and maximal frontal positivity) and typical clinical features of benign epilepsy of childhood with centrotemporal spikes, including good prognosis, has been proposed ${ }^{1,2,4,10-14}$. On the other hand, the occurrence of "double spike" (a non stationary pattern characterized by an initial reversed tangential dipole polarity followed by the usual dipole pattern) was suggested to be related to an increased occurrence of epileptic seizures ${ }^{6-9}$.

Given these proposed associations, during EEG visual analysis, the characterization of these specific

Laboratory of Clinical Neurophysiology, Neurology and Neurosurgery Department, UNIFESP-EPM, São Paulo SP, Brazil: ${ }^{1}$ Associate Professor; ${ }^{2}$ Head of Department.

Received 18 March 2002. Accepted 29 May 2002.

Dra. Nadia I. O. Braga - Rua Brigadeiro Jordão 108 - 04210-000 São Paulo SP - Brasil. E-mail: niobraga@uol.com.br 
spike patterns (i.e. tangential dipole and occurrence of "double spike") become particularly important. However, the clinical utilization of these informations rests on the unproven assumption of the occurrence of these specific patterns in all the individual spikes observed through an entire EEG recording.

The aim of this study is to assess the relationship between the amount of individual spikes showing these patterns and its expression in the averaged waveform.

\section{METHOD}

Twenty-four patients, 14 between 10 and 12 years old (mean 11.1) and 9 between 7 and 9 years old (mean 8.5) were selected, based on the presence of epileptiform discharges with their maximum at the centrotemporal region, uni or bilaterally, on at least 1 EEG study, independent of the occurrence of specific discharge patterns.

Twenty-one channel digital EEG were recorded with electrodes placed according to the $10-20$ system $^{15}$ including Fpz and Oz. Reference electrodes were placed on $\mathrm{M} 1$ and $\mathrm{M} 2$ positions ${ }^{16}$. $\mathrm{Ag}-\mathrm{AgCl}$ disk electrodes were applied with conductive paste, keeping impedances below $5 \mathrm{kOhm}$. Twenty minutes of EEG were recorded, ten minutes during wakefulness, with eyes closed and ten minutes during sleep, simultaneously on the Nicolet Pathfinder Mega system and on the Easy digital electroencephalograph; this setting allowed the simultaneous visualization of all channels during the recordings. The EEG signal was recorded with a sensitivity of $10 \mathrm{~V} / \mathrm{mm}$, bandpass filtered from 0.5 to $70 \mathrm{~Hz}$ and sampled at $256 \mathrm{~Hz}$.

The epileptiform discharges were analyzed during sleep, where they occurred more frequently. The twenty largest amplitude discharges of each tracing were selected, provided that the largest amplitude was measured on the same electrode; on those tracings with bilateral discharges only the more active focus was analyzed. The individual discharges were visually analyzed and classified according to the presence of tangential dipole, double spike or none of them. These same discharges were then averaged after manual alignment on the maximum amplitude peak, and the resulting waveform was classified on the same way.

The study was approved by the local ethic committee.

\section{RESULTS}

In the 24 averaged spikes, tangential dipole was present in 15 and "double spike" morphology in 11. In the 15 averaged discharges classified as tangential dipole present, 35 to $100 \%$ of the individual spikes had the same pattern, while in the remaining nine averaged discharges (no tangential dipole), up to $20 \%$ of individual spikes presented the tangential dipole pattern.

In the 11 averaged spikes classified as "double spike", 50 to $100 \%$ of the individual spikes had the same pattern, whereas up to $45 \%$ of the individual spikes had this pattern in the remaining 13 (no "double spike").

The findings from the individual patients are summarized in the Table 1. Illustrative recordings are shown in Figures 1 and 2.

\section{DISCUSSION}

Morphological aspects of rolandic spikes and clinical features have been studied for the two past decades, always based upon findings on averaged discharges ${ }^{1,4,6-9,13,14}$. The utilization of this information in the analysis of the individual epileptiform discharges, during visual analysis of an EEG, rests upon the supposition that all discharges display the same morphological features during an EEG recording. However, this assumption is hampered by arguments such as those forwarded by Yoshinaga et al. ${ }^{14}$ that

Table 1. Averaged $x$ individual patterns.

\begin{tabular}{|c|c|c|c|c|}
\hline \multirow{2}{*}{$\begin{array}{l}\text { Case } \\
\text { No. }\end{array}$} & \multicolumn{2}{|c|}{ Tangential dipole } & \multicolumn{2}{|c|}{ "Double spike" } \\
\hline & Aver. & Individ.* & Aver. & Individ.* \\
\hline 1 & + & $17(85 \%)$ & - & $4(20 \%)$ \\
\hline 2 & + & $9(45 \%)$ & - & $9(45 \%)$ \\
\hline 3 & + & $11(55 \%)$ & + & $13(65 \%)$ \\
\hline 4 & + & $12(60 \%)$ & + & $12(60 \%)$ \\
\hline 5 & + & $10(50 \%)$ & - & $0(0 \%)$ \\
\hline 6 & + & $20(100 \%)$ & + & $20(100 \%)$ \\
\hline 7 & - & $0(0 \%)$ & + & $20(100 \%)$ \\
\hline 8 & - & $1(5 \%)$ & - & $6(30 \%)$ \\
\hline 9 & - & $1(5 \%)$ & - & $0(0 \%)$ \\
\hline 10 & + & $20(100 \%)$ & - & $9(45 \%)$ \\
\hline 11 & + & $12(60 \%)$ & - & $7(35 \%)$ \\
\hline 12 & + & 7 (35\%) & + & $10(50 \%)$ \\
\hline 13 & + & $11(55 \%)$ & + & $11(55 \%)$ \\
\hline 14 & - & $0(0 \%)$ & - & $4(20 \%)$ \\
\hline 15 & - & $0(0 \%)$ & + & $10(50 \%)$ \\
\hline 16 & + & 19 (95\%) & + & $10(50 \%)$ \\
\hline 17 & - & $0(0 \%)$ & - & $0(0 \%)$ \\
\hline 18 & + & $14(70 \%)$ & - & $6(30 \%)$ \\
\hline 19 & + & $20(100 \%)$ & + & $16(80 \%)$ \\
\hline 20 & - & $0(0 \%)$ & + & $10(50 \%)$ \\
\hline 21 & + & $20(100 \%)$ & + & 15 (75\%) \\
\hline 22 & - & $04(20 \%)$ & - & $5(25 \%)$ \\
\hline 23 & - & $1(5 \%)$ & - & $3(15 \%)$ \\
\hline 24 & + & 19 (95\%) & - & $0(0 \%)$ \\
\hline
\end{tabular}




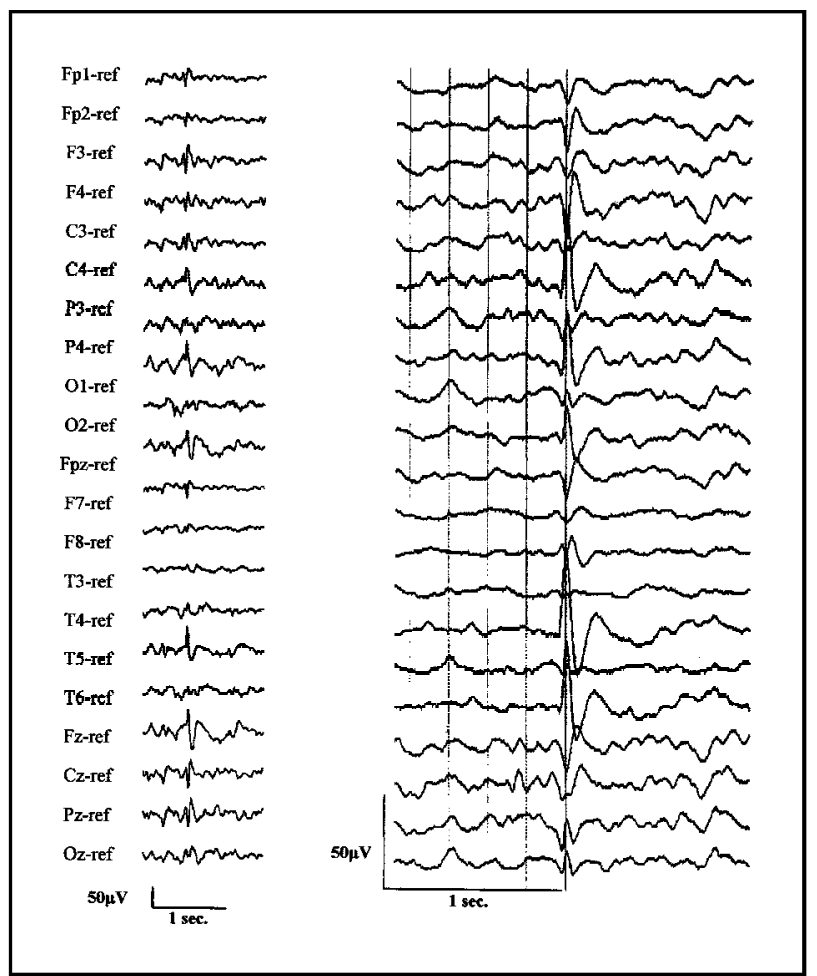

Fig 1. Example of tangential dipole (left rolandic spike). On the left: individual spike; on the right: averaged spike.

the precision of the estimated field is improved by averaging, because it removes the interactions between the discharges and the background activity, which implies that this could potentially distort the morphological characteristics of the discharge. Besides, it should be also reminded that the epileptiform discharges may show morphological differences related to minor changes of the epileptiform area from one discharge to another.

According to our results, the identification of "double spike" pattern in the averaged discharges relates to the frequent characterization $(\geq 50 \%)$ of the pattern in a sample of individual spikes; for the characterization of the tangential dipole pattern in the averaged spike a smaller percentage ( $\geq 35 \%)$ of individual discharges showing this pattern is required.

In conclusion, our findings suggest that, when visually analyzing an EEG with rolandic spikes, caution should be exercised before the characterization of these patterns, since a few discharges showing them may not be expressed in the averaged waveform and the clinical correlations proposed for these patterns may not apply.

\section{REFERENCES}

1. Wong PKH, Bencivenga R, Gregory D. Statistical classification of spikes in benign rolandic epilepsy. Brain Topography 1988;1:123-129.
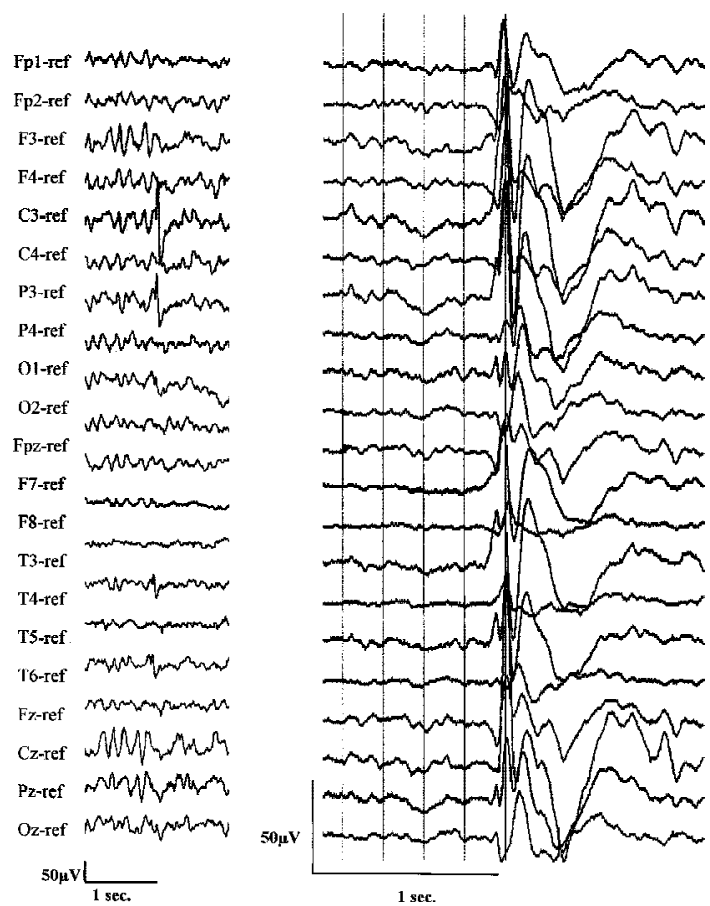

Fig 2. Example of double spike (left rolandic spike). On the left: individual spike; on the right: averaged spike.

2. Wong PKH. The importance of source behavior in distinguishing populations of epileptic foci. J Clin Neurophysiol 1993;10:314-322.

3. Baumgartner C, Graf M, Doppelbauer A, et al. The functional organization of the interictal spike complex in benign rolandic epilepsy. Epilepsia 1996;37:1164-1174.

4. Gregory D, Wong PKH. Clinical relevance of a dipole field in rolandic spikes. Epilepsia 1992;33:36-44.

5. Minami T, Gondo K, Yamamoto T, Yanai S, Takasi K, Ueda K Magnetoencephalographic analysis of rolandic discharges in benign childhood epilepsy. Ann Neurol 1996;39:326-334.

6. Van Der Meij W, Van Huffelen AC, Willemse J, Schenk-Rootlieb AJF Meiners LC. Rolandic spikes in the inter-ictal EEG of children contribution to diagnosis, classification and prognosis of epilepsy. Dev Med Child Neurol 1992;34:893-903.

7. Van Der MeijW, Van Huffelen AC, Wieneke GH, Willemse J. Sequential EEG mapping may differentiate "epileptic " from "non-epileptic" rolandic spikes. Electroenceph Clin Neurophysiol 1992;82:408-414.

8. Van Der Meij W, Wieneke GH, Van Huffelen AC. Dipole source analysis of rolandic spikes in benign rolandic epilepsy and other clinical syndromes. Brain Topography 1993;5:203-213.

9. Van Der Meij W, Wieneke GH, Van Huffelen AC, Schenk-Rootlieb AJF, Willemse J. Identical morphology of the rolandic spike-and-wave complex in different clinical entities. Epilepsia 1993;34:540-550.

10. Weinberg H, Wong PKH, Crisp D, Johnson B, Cheyne D. Use of multiple dipole analysis for the classification of benign rolandic epilepsy. Brain Topography 1990;3:183-190.

11. Wong PKH. Stability of source estimates in rolandic spikes. Brain Topography 1989;2:31-36.

12. Wong PKH. Dynamic correlation of rolandic spikes. Brain Topography 1990;3:129-136.

13. Yoshinaga H, Amano R, Oka E, Ohtahara S. Dipole tracing in childhood epilepsy with special reference to rolandic epilepsy. Brain Topography 1992;4:193-199.

14. Yoshinaga H, Kobayashi K, Sato M, Mizukawa M, Ohtahara S. Clinical application of spike averaging to dipole tracing method. Brain Topography 1993;6:131-135.

15. Jasper HH. Report of the committee on methods of clinical examination in electroencephalography. Electroenceph Clin Neurophysiol 1958;10:370-375

16. Gregory D, Wong PKH. Topographical analysis of the centrotemporal discharges in benign rolandic epilepsy of childhood. Epilepsia 1984;25:705-711. 